Check for updates

Cite this: RSC Adv., 2021, 11, 14229

Received 15th January 2021

Accepted 4th April 2021

DOI: $10.1039 / \mathrm{d} 1 \mathrm{ra00350j}$

rsc.li/rsc-advances

\section{Sesquiterpenoids of diverse types from the rhizomes of Acorus calamus $\dagger$}

\author{
Zhi-You Hao, (D) *ab Yan-Fei Liu, ${ }^{\mathrm{b}}$ Yan-Gang Cao, ${ }^{\mathrm{a}}$ Dong Liang, ${ }^{\mathrm{b}}$ Huan Luo, \\ Chun-Lei Zhang, ${ }^{\mathrm{b}}$ Yan Wang, ${ }^{\mathrm{b}}$ Ruo-Yun Chen ${ }^{\mathrm{b}}$ and De-Quan Yu${ }^{* \mathrm{~b}}$
}

\begin{abstract}
Six new sesquiterpenoids (1-6), named calamusins $L-Q$, together with fourteen known ones were isolated from the ethanol extract of the rhizomes of Acorus calamus. The new compounds and their absolute configurations were determined based on extensive spectroscopic analyses and computational methods. All of the new compounds were evaluated for their neuroprotective effect against serum withdrawal, rotenone, and OGD-induced PC12 cell injury, and it was revealed that compounds 1 and 6 increased the cell survival rate of the OGD-treated PC12 cells moderately at $10 \mu \mathrm{M}$.
\end{abstract}

\section{Introduction}

Acorus calamus Linn. (Chinese name is "Shui Chang Pu") is a perennial aquatic plant of the family Araceae, and widely distributed in China. ${ }^{1}$ The rhizomes of Acorus calamus were commonly used in traditional Chinese medicine to treat amnesia, phlegm syncope, epilepsy, rheumatism, and various mental illnesses. Previous bioactive studies displayed the plant possesses antitumor, ${ }^{2-4}$ antivirus, ${ }^{5,6}$ antibacterial, ${ }^{7,8}$ neuroprotective, ${ }^{9-11}$ antidiabetic ${ }^{12}$ and anti-inflammatory ${ }^{13}$ activities. Especially, extensive clinical evidence proved it was effective to treat neurological disorders, such as Alzheimer's disease, Parkinson's disease, senile memory impairment, and schizophrenia. ${ }^{14,15}$ Probably, one reason A. calamus could treat these diseases was its neuroprotective bioactivities. Chemical investigation indicated it contains wide variety of sesquiterpenoids, ${ }^{16-19}$ phenylpropanoids, lignans, alkaloids, ${ }^{20}$ flavonoids, steroids, triterpenoid saponins, and volatiles. ${ }^{21-23}$ Among them, $\beta$-asarone, a phenylpropanoid, was reported mostly and regarded as the main neuroprotective constituent of $A$. calamus. ${ }^{24-27}$ However, toxicological studies suggested it possess carcinogenicity and genetic toxicity. ${ }^{28,29}$ Apparently, in this sense, it's not reasonable to view $\beta$-asarone as the representative neuroprotective constituent of $A$. calamus. Therefore, it is necessary to evaluate the neuroprotective bioactivities of other types of compounds.

Our previous study on the $95 \%$ aqueous ethanol extract of $A$. calamus reported nine new sesquiterpenoids (calamusins A-I)

${ }^{a}$ School of Pharmacy, Henan University of Chinese Medicine, Zhengzhou 450046, P. R. China.E-mail: hzy@hactcm.edu.cn

${ }^{b}$ State Key Laboratory of Bioactive Substance and Function of Natural Medicines, Institute of Materia Medica, Chinese Academy of Medical Sciences, Peking Union Medical College, Beijing 100050, P. R. China.E-mail: dqyu@imm.ac.cn

$\dagger$ Electronic supplementary information (ESI) available: UV, IR, ECD, MS, 1D and 2D NMR spectra for compounds 1-6. See DOI: 10.1039/d1ra00350j and their bioactivities. ${ }^{16}$ During the continued investigation, six new (1-6) and fourteen known sesquiterpenoids of diverse types were characterized. The isolation and structure elucidation of these compounds are described herein, as well as the in vitro neuroprotective assays of the new compounds (Fig .1).

\section{Results and discussion}

Calamusin L (1) was assigned the molecular formula $\mathrm{C}_{15} \mathrm{H}_{22} \mathrm{O}_{6}$, with 5 hydrogen deficiencies, as deduced from HRESIMS $(\mathrm{m} / \mathrm{z}$ 299.1490 $\left.[\mathrm{M}+\mathrm{H}]^{+}, m / z 321.1313[\mathrm{M}+\mathrm{Na}]^{+}\right)$and NMR data. The IR spectrum showed the absorptions of hydroxy $\left(3390 \mathrm{~cm}^{-1}\right)$ and carbonyl $\left(1708,1651 \mathrm{~cm}^{-1}\right)$ groups. The ${ }^{1} \mathrm{H}$ NMR spectrum of 1 (Table 1) showed two secondary methyl groups $\left[\delta_{\mathrm{H}} 0.68(\mathrm{~d}, J\right.$ $=6.8 \mathrm{~Hz})$, Me-12; $1.01(\mathrm{~d}, J=6.6 \mathrm{~Hz}), \mathrm{Me}-13]$, two tertiary methyl groups $\left[\delta_{\mathrm{H}} 1.84(\mathrm{~s}), \mathrm{Me}-14 ; 1.29(\mathrm{~s}), \mathrm{Me}-15\right]$, an oxygenated
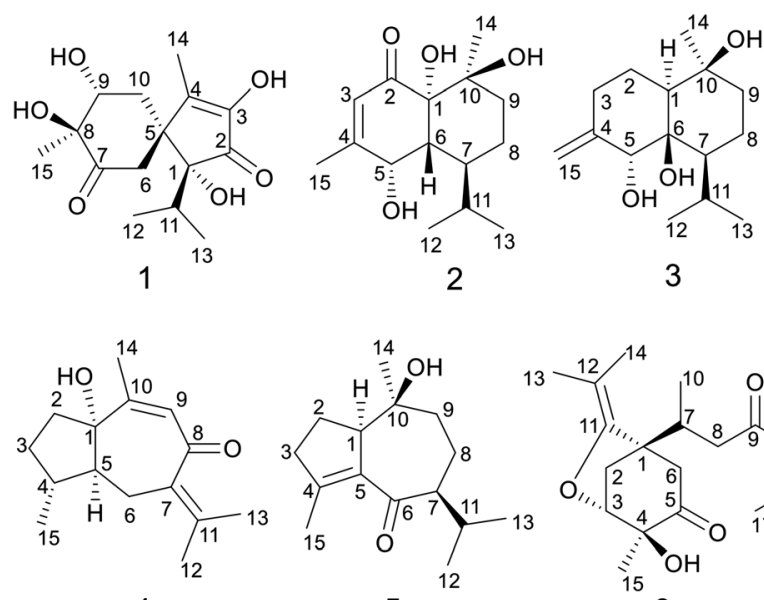

4
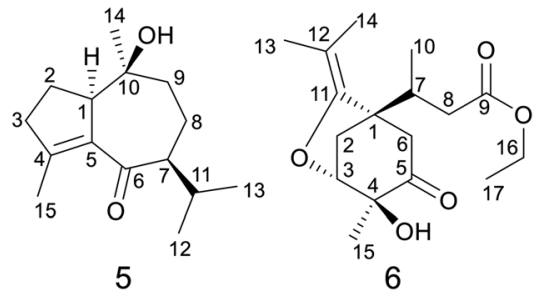

Fig. 1 Chemical structures of compounds 1-6. 
Table $1{ }^{1} \mathrm{H}$ NMR data of compounds $1-3$ in acetone- $d_{6}(\delta$ in ppm, $J$ in $\mathrm{Hz})^{a}$

\begin{tabular}{|c|c|c|c|}
\hline No. & 1 & 2 & 3 \\
\hline 1 & & & $1.84(\mathrm{dd}, 12.8 / 3.4)$ \\
\hline \multirow[t]{2}{*}{2} & & & $1.91(\mathrm{~m})$ \\
\hline & & & $1.37(\mathrm{~m})$ \\
\hline \multirow[t]{2}{*}{3} & & 5.72 (brs) & $2.35(\mathrm{~m})$ \\
\hline & & & $2.10(\mathrm{~m})$ \\
\hline 5 & & $4.29(\mathrm{~m})$ & $4.02(\mathrm{~s})$ \\
\hline 6 & 2.80 (overlap) & $2.18(\mathrm{dd}, 12.0 / 3.6)$ & \\
\hline 7 & & $1.99(\mathrm{~m})$ & $1.71(\mathrm{~m})$ \\
\hline \multirow[t]{2}{*}{8} & & 1.48 (overlap) & $1.52(\mathrm{~m})$ \\
\hline & & $1.38(\mathrm{~m})$ & 1.45 (overlap) \\
\hline \multirow[t]{2}{*}{9} & $3.91(\mathrm{~m})$ & $1.73(\mathrm{~m})$ & $1.75(\mathrm{~m})$ \\
\hline & & 1.48 (overlap) & 1.45 (overlap) \\
\hline \multirow[t]{2}{*}{10} & $2.28(\mathrm{~m})$ & & \\
\hline & $1.71(\mathrm{~m})$ & & \\
\hline 11 & $2.04(\mathrm{~m})$ & $2.13(\mathrm{~m})$ & $2.16(\mathrm{~m})$ \\
\hline 12 & $0.68(\mathrm{~d}, 6.8)$ & $0.96(\mathrm{~d}, 7.2)$ & $0.91(\mathrm{~d}, 6.9)$ \\
\hline 13 & $1.01(\mathrm{~d}, 6.6)$ & $0.76(\mathrm{~d}, 7.2)$ & $0.88(\mathrm{~d}, 6.9)$ \\
\hline 14 & $1.84(\mathrm{~s})$ & $1.42(\mathrm{~s})$ & $1.14(\mathrm{~s})$ \\
\hline 15 & $1.29(\mathrm{~s})$ & $2.05(\mathrm{~d}, 1.2)$ & $4.84(\mathrm{~s})$ \\
\hline $\mathrm{OH}$ & & $5.08(\mathrm{~s}, 1-\mathrm{OH})$ & \\
\hline $\mathrm{OH}$ & & $4.96(\mathrm{~d}, 7.2,5-\mathrm{OH})$ & \\
\hline $\mathrm{OH}$ & & 2.92 (brs, $10-\mathrm{OH})$ & \\
\hline
\end{tabular}

methine group $\left[\delta_{\mathrm{H}} 3.91(\mathrm{~m}), \mathrm{H}-9\right]$, and other five aliphatic protons. The ${ }^{13} \mathrm{C}$ NMR (Table 3) and DEPT spectra of $\mathbf{1}$ exhibited 15 carbon resonances corresponding to four methyls, two methylenes, two methines (one aliphatic, $\delta_{\mathrm{C}} 35.3$; one oxygenated, $\delta_{\mathrm{C}} 74.7$ ), and seven quaternary carbons (two oxygenated ones at $\delta_{\mathrm{C}} 85.2$ and 80.1; an aliphatic one at $\delta_{\mathrm{C}} 51.9$; two olefinic ones at $\delta_{\mathrm{C}} 149.2$ and 146.1; an $\alpha, \beta$-unsaturated keto carbonyl group at $\delta_{\mathrm{C}} 200.8$; an saturated keto carbonyl group at $\delta_{\mathrm{C}} 213.7$ ). Analysis of ${ }^{1} \mathrm{H}^{-}{ }^{1} \mathrm{H}$ COSY spectrum revealed the presence of two discrete spin systems (Fig. 2) corresponding to a $-\mathrm{CH}-\mathrm{CH}_{2}$ - unit (C9-C10) and a $\mathrm{CH}_{3}-\mathrm{CH}-\mathrm{CH}_{3}$ moiety (C12-C11-C13, an isopropyl group). The HMBC correlations (Fig. 2) were displayed from $\mathrm{H}-14 / 10 / 6$ to C-5/4, Me-15 to C-7/8/9, and Me-13/Me-12 to $\mathrm{C}-1$, allowing the establishment of an acorane-type sesquiterpene skeleton, which exists extensively in genus Acorus. ${ }^{16,30}$ Furthermore, NOESY correlations (Fig. 2) between H-11/12/13 and $\mathrm{H}-6, \mathrm{Me}-14 / 10 \mathrm{~b}\left(\delta_{\mathrm{H}} 1.71, \beta\right)$ and $\mathrm{H}-9(\beta), \mathrm{H}-10 \mathrm{a}\left(\delta_{\mathrm{H}} 2.28, \alpha\right)$ and $\mathrm{H}-15(\alpha)$ determined the relative configuration of 1 . The absolute configuration of $\mathbf{1}$ was obtained by analyses of CD spectrum. According to the octant rule of saturated cyclohexanones, ${ }^{31}$ the negative Cotton effect that occurred at $273 \mathrm{~nm}(\Delta \varepsilon$ -1.29 ) based on the $\mathrm{n} \rightarrow \pi^{*}$ transition of cyclohexanone indicated that the configuration of compound $\mathbf{1}$ is $1 R, 5 S, 8 S, 9 R$.

The molecular formula of calamusin M (2) was determined to be $\mathrm{C}_{15} \mathrm{H}_{24} \mathrm{O}_{4}$, with four hydrogen deficiencies, on the basis of HRESIMS $\left(\mathrm{m} / \mathrm{z} 291.1575[\mathrm{M}+\mathrm{Na}]^{+}\right)$. The UV spectrum showed the absorption of an $\alpha, \beta$-unsaturated carbonyl at $226 \mathrm{~nm}$. The IR spectrum showed absorption bands corresponding to hydroxy $\left(3384 \mathrm{~cm}^{-1}\right)$ and carbonyl $\left(1670 \mathrm{~cm}^{-1}\right)$ groups. The ${ }^{1} \mathrm{H}$ NMR spectrum (Table 1) showed signals corresponding to the
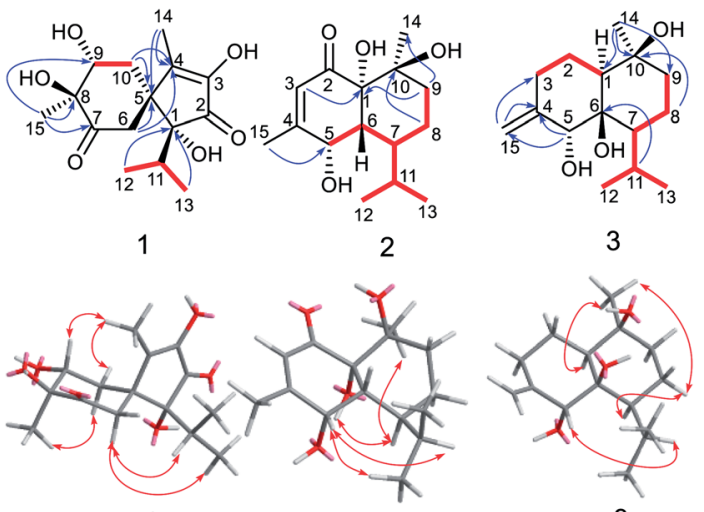

1

2
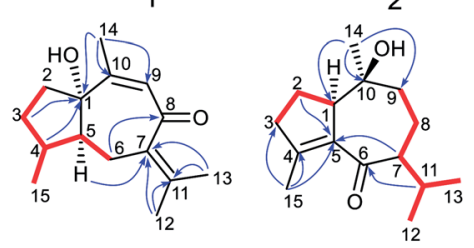

3

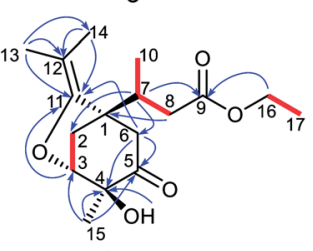

4

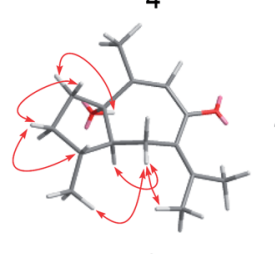

5
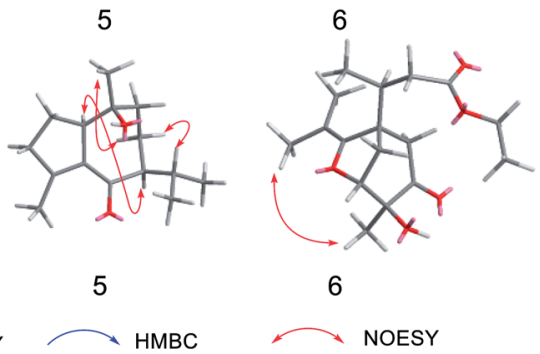

$\left[{ }^{1} \mathrm{H}-{ }^{1} \mathrm{H}\right.$ COSY

HMBC

$\sim$ NOESY

Fig. $2{ }^{1} \mathrm{H}-{ }^{1} \mathrm{H}$ COSY, HMBC, and NOESY correlations of compounds $1-6$.

protons of two secondary methyl groups $\left[\delta_{\mathrm{H}} 0.96(\mathrm{~d}, J=7.2 \mathrm{~Hz})\right.$, Me-12; 0.76 (d, $J=7.2 \mathrm{~Hz}$ ), Me-13], an olefinic tertiary methyl group $\left[\delta_{\mathrm{H}} 2.05(\mathrm{~d}, J=1.2 \mathrm{~Hz})\right.$, Me-15], an aliphatic tertiary methyl group $\left[\delta_{\mathrm{H}} 1.42(\mathrm{~s}), \mathrm{Me}-14\right]$, one olefinic methine $\left[\delta_{\mathrm{H}} 5.72\right.$ (brs), $\mathrm{H}-3]$, and an oxygen-bearing methine $\left[\delta_{\mathrm{H}} 4.29(\mathrm{~m}), \mathrm{H}-5\right]$. ${ }^{13} \mathrm{C}$ NMR (Table 3) and DEPT-135/90 spectra showed 15 signals corresponding to four methyl groups, two methylene groups, five methines (an oxygenated one at $\delta_{\mathrm{C}} 68.0$; three aliphatic ones at $\delta_{\mathrm{C}} 43.1,38.0$, and 26.2; an olefinic one at $\delta_{\mathrm{C}}$ 125.7), four quaternary carbons [an olefinic quaternary carbon at $\delta_{\mathrm{C}} 159.1$; two oxygenated quaternary carbons at $\delta_{\mathrm{C}} 77.9$ and 72.4; an $\alpha, \beta$-unsaturated keto carbonyl group at $\left.\delta_{\mathrm{C}} 201.4\right]$. The cross peaks of ${ }^{1} \mathrm{H}^{-1} \mathrm{H}$ COSY spectrum suggested the presence of C9-C8-C7-C6-C5 and C12-C11(C7)-C13 moieties (Fig. 2). Additionally, coupling constant of Me-15 $(1.2 \mathrm{~Hz})$ in the ${ }^{1} \mathrm{H}$ NMR spectrum and the weak cross signal of ${ }^{1} \mathrm{H}-{ }^{1} \mathrm{H}$ COSY spectrum between Me-15 and H-3 suggested an allylic system of C15-C4$\mathrm{C} 3$ is present in the structure. The HMBC correlations (Fig. 2) from Me-15 to C-5, H-8 to C-10, $\mathrm{H}-9$ to $\mathrm{C}-1 / 14$, and $\mathrm{H}-3$ to $\mathrm{C}-1$ suggested C-5 is linked with C-4, C-10 is linked with C-9, C-10/ Me-14 are linked with C-10, and C-1 is linked with C-2. The above data, similar to those of tatarinowin $\mathrm{C},{ }^{32}$ suggested that compound 2 possessed a cadinane-type sesquiterpene carbon skeleton. Analysis of the chemical shifts and degrees of unsaturation indicated that $\mathrm{C}-1, \mathrm{C}-5$, and $\mathrm{C}-10$ are all linked with 
hydroxy groups. The combined analysis of coupling constant and NOESY spectrum allowed the determination of the relative configuration of 2 . The rather small coupling constant $(3.5 \mathrm{~Hz})$ between $\mathrm{H}-5$ and $\mathrm{H}-6$ indicated that the two protons are cisoriented ( $\beta$-oriented). Furthermore, the NOESY correlations (Fig. 2) of $\mathrm{H}-5$ with $\mathrm{H}-11 / \mathrm{Me}-13$ suggested the isopropyl group is $\beta$-oriented, and $\mathrm{H}-7$ is $\alpha$-oriented. In addition, the NOESY correlations of $\mathrm{H}-7$ with 1-OH/Me-14 suggested 1-OH and Me-14 are both $\alpha$-oriented. According to the octant rule of $n \rightarrow \pi^{*}$ transition of $\alpha, \beta$-unsaturated cyclohexanone unit, the absolute configuration of 2 was determined to be $1 S, 5 S, 6 R, 7 S, 10 S$ on the basis of the positive Cotton effect observed in the CD spectrum at $343 \mathrm{~nm}(\Delta \varepsilon+1.03){ }^{33}$

Calamusin N (3) was assigned the molecular formula $\mathrm{C}_{15} \mathrm{H}_{26} \mathrm{O}_{3}$, with 3 hydrogen deficiencies, as deduced from HRESIMS $\left(\mathrm{m} / \mathrm{z} 277.1777[\mathrm{M}+\mathrm{Na}]^{+}\right)$and NMR data. The IR spectrum showed bands corresponding to hydroxy groups (3372 and $3288 \mathrm{~cm}^{-1}$ ). ${ }^{1} \mathrm{H}$ NMR spectrum (Table 1) showed proton signals corresponding to two secondary methyl groups $\left[\delta_{\mathrm{H}} 0.91\right.$ (d, $J=6.9 \mathrm{~Hz}$ ), Me-12; 0.88 (d, $J=6.9 \mathrm{~Hz}$ ), Me-13], one tertiary methyl group $\left[\delta_{\mathrm{H}} 1.14(\mathrm{~s}), \mathrm{Me}-14\right]$, an oxygen-bearing methine group $\left[\delta_{\mathrm{H}} 4.02(\mathrm{~s}), \mathrm{H}-5\right]$, and two olefinic protons $\left[\delta_{\mathrm{H}} 4.84(2 \mathrm{H}, \mathrm{s})\right.$, $\mathrm{H}-15] \cdot{ }^{13} \mathrm{C}$ NMR (Table 3) and DEPT-135/90 spectra showed 15 carbon signals corresponding to three methyl groups, five methylene groups (four aliphatic ones at $\delta_{\mathrm{C}} 22.9,30.5,19.6$, and 44.1; an olefinic one at $\delta_{\mathrm{C}} 112.4$ ), three methines (an oxygenated one at $\delta_{\mathrm{C}} 76.2$ ), as well as three quaternary carbons (two oxygenated ones at $\delta_{\mathrm{C}} 77.7$ and 72.1 ; an olefinic one at $\delta_{\mathrm{C}} 150.4$ ). The cross signals of ${ }^{1} \mathrm{H}^{-1} \mathrm{H}$ COSY spectrum (Fig. 2) of 3 suggested the presence of $\mathrm{C} 9-\mathrm{C} 8-\mathrm{C} 7-\mathrm{C} 11(\mathrm{C} 12)-\mathrm{C} 13$ and $\mathrm{C} 1-\mathrm{C} 2-\mathrm{C} 3$ structural moieties. Additionally, the observed HMBC (Fig. 2) correlations between $\mathrm{H}-15$ and $\mathrm{C}-4 / \mathrm{C}-3, \mathrm{H}-5$ and C-4/C-15, $\mathrm{H}-11$ and $\mathrm{C}-6, \mathrm{H}-8$ and $\mathrm{C}-10$, and Me- 14 and $\mathrm{C}-1 / 9 / 10$ suggested $\mathrm{C}-4$ is linked with C-3/5/15, C-6 is linked with C-7, C-10 is linked with $\mathrm{C}-9$, and $\mathrm{C}-10$ is attached to $\mathrm{C}-1$ and $\mathrm{C}-14$, allowing the establishment of a cadinene-type sesquiterpene carbon skeleton. The NOESY spectrum showed correlations (Fig. 2) of $\mathrm{H}-5$ and $\mathrm{H}-11$, $\mathrm{H}-7$ and $\mathrm{H}-8 \mathrm{a}(\delta$ 1.52), $\mathrm{H}-8 \mathrm{a}$ and Me-14, Me-14 and H-1, which indicated $5-\mathrm{OH} / \mathrm{Me}-14 / \mathrm{H}-1$ are $\alpha$-oriented, the isopropyl group at position 7 and $10-\mathrm{OH}$ are $\beta$-oriented. As the structural analysis, $\mathrm{H}-5$ and $\mathrm{H}-7$ should be closely spatially if $6-\mathrm{OH}$ was $\alpha$ oriented, but the correlation was not appeared between the above two in the NOESY spectrum, indicating $6-\mathrm{OH}$ is $\beta$ oriented.

Determination of the absolute configuration of 3 was implemented by comparison of the experimental and calculated specific optical rotation (SOR) of the two stereoisomers. The SOR of each configuration of 3 was calculated using DFT theory method at the pbe1pbe/aug-cc-pVTZ level. Finally, the calculated SOR of $(1 S, 5 R, 6 R, 7 S, 10 S)-3\left([\alpha]_{\mathrm{D}}+41.9\right)$ had the same trend as the experimental vale $\left([\alpha]_{\mathrm{D}}+23.4, \mathrm{MeOH}\right)$, while the calculated data of $(1 R, 5 S, 6 S, 7 R, 10 R)-3\left([\alpha]_{\mathrm{D}}-42.8\right)$ had the opposite sign to the experimental value, indicating the absolute configuration of 3 was $1 S, 5 R, 6 R, 7 S, 10 S$.

The molecular formula of calamusin $\mathrm{O}(4)$ was determined to be $\mathrm{C}_{15} \mathrm{H}_{22} \mathrm{O}_{2}$ by HRESIMS $\left(\mathrm{m} / \mathrm{z} 235.1688[\mathrm{M}+\mathrm{H}]^{+}\right)$and NMR spectra. The ${ }^{1} \mathrm{H}$ NMR spectrum (Table 2) showed signals
Table $2{ }^{1} \mathrm{H}$ NMR data of compounds $4-6$ in acetone- $d_{6}(\delta$ in ppm, $J$ in $\mathrm{Hz})^{a}$

\begin{tabular}{llll}
\hline No. & $\mathbf{4}$ & $\mathbf{5}$ & $\mathbf{6}$ \\
\hline 1 & & $3.23(\mathrm{~m})$ & \\
2 & $1.99(\mathrm{~m})$ & $1.94(\mathrm{~m})$ & $2.29(\mathrm{~d}, 12.0)$ \\
& $1.92($ overlap$)$ & & $2.08($ overlap$)$ \\
3 & $1.84($ overlap) & $2.41(\mathrm{~m})$ & $4.14(\mathrm{~d}, 6.0)$ \\
& $1.25(\mathrm{~m})$ & $2.32(\mathrm{~m})$ & \\
4 & $2.74(\mathrm{~m})$ & & \\
5 & $1.85(\mathrm{~m})$ & & $2.94(\mathrm{~d}, 15.6)$ \\
6 & $2.62(\mathrm{~d}, 12.6)$ & & $2.28(\mathrm{dd}, 15.6 / 3.0)$ \\
& $1.83($ overlap$)$ & & $2.57(\mathrm{~m})$ \\
7 & & $2.29(\mathrm{ddd}, 11.4 / 6.0 / 1.8)$ & $2.10(\mathrm{dd}, 15.0 / 3.6)$ \\
8 & & $1.82(\mathrm{~m})$ & \\
& & $1.17(\mathrm{~m})$ & $0.96(\mathrm{~d}, 7.2)$ \\
9 & $5.67(\mathrm{q}, 1.2)$ & $1.95(\mathrm{overlap})$ & \\
& & $1.76(\mathrm{td}, 13.2 / 3.6)$ & $1.56(\mathrm{~s})$ \\
10 & & & $1.57(\mathrm{~s})$ \\
11 & & $2.05(\mathrm{~m})$ & $1.27(\mathrm{~s})$ \\
12 & $1.92(\mathrm{~s})$ & $0.88(\mathrm{~d}, 6.6)$ & $4.12(\mathrm{q}, 7.2)$ \\
13 & $1.82(\mathrm{~s})$ & $0.89(\mathrm{~d}, 5.4)$ & $1.22(\mathrm{t}, 7.2)$ \\
14 & $1.95(\mathrm{~d}, 1.2)$ & $0.90(\mathrm{~s})$ & $4.71(\mathrm{~s})$ \\
15 & $1.08(\mathrm{~d}, 7.0)$ & $1.99(\mathrm{~m})$ & \\
16 & & & \\
17 & & & \\
OH & $3.80(\mathrm{~s}, 6-\mathrm{OH})$ & & \\
$a$ & & & \\
Measured at 600 MHz. & & \\
& & &
\end{tabular}

corresponding to the protons of three tertiary methyl groups $\left[\delta_{\mathrm{H}}\right.$ $1.92(\mathrm{~s}), \mathrm{Me}-12 ; 1.82(\mathrm{~s}), \mathrm{Me}-13 ; 1.95(\mathrm{~d}, J=1.2 \mathrm{~Hz}), \mathrm{Me}-14]$, one secondary methyl groups $\left[\delta_{\mathrm{H}} 1.08(\mathrm{~d}, J=7.0 \mathrm{~Hz}), \mathrm{Me}-15\right]$, and an olefinic proton $\left[\delta_{\mathrm{H}} 5.67(\mathrm{q}, J=1.2 \mathrm{~Hz}), \mathrm{H}-9\right] .{ }^{13} \mathrm{C}$ NMR (Table 3) and DEPT-135/90 spectra displayed 15 signals corresponding to four methyl groups, three methylenes, three methines (two

Table $3{ }^{13} \mathrm{C}$ NMR data of compounds $1-6(150 \mathrm{MHz})$ in acetone- $d_{6}(\delta$ in ppm)

\begin{tabular}{lrrrrrr}
\hline No. & \multicolumn{1}{c}{1} & \multicolumn{1}{c}{3} & \multicolumn{1}{c}{4} & \multicolumn{1}{c}{5} & \multicolumn{1}{c}{6} \\
\hline 1 & 85.2 & 77.9 & 48.6 & 86.0 & 57.0 & 49.8 \\
2 & 200.8 & 201.4 & 22.9 & 38.1 & 24.3 & 33.6 \\
3 & 149.2 & 125.7 & 30.5 & $29.8^{a}$ & 39.2 & 81.1 \\
4 & 146.1 & 159.1 & 150.4 & 36.8 & 154.8 & 74.7 \\
5 & 51.9 & 68.0 & 76.2 & 56.0 & 138.1 & 207.7 \\
6 & 39.7 & 43.1 & 77.7 & 24.9 & 203.5 & 49.2 \\
7 & 213.7 & 38.0 & 46.2 & 135.7 & 58.5 & 34.6 \\
8 & 80.1 & 18.7 & 19.6 & 194.6 & 25.0 & 38.6 \\
9 & 74.7 & 37.3 & 44.1 & 128.1 & 47.5 & 173.1 \\
10 & 43.1 & 72.4 & 72.1 & 153.8 & 74.1 & 15.0 \\
11 & 35.3 & 26.2 & 25.1 & 141.2 & 28.4 & 151.1 \\
12 & 21.2 & 21.9 & 24.2 & 23.0 & 21.4 & 101.5 \\
13 & 17.4 & 15.3 & 18.9 & 22.3 & 19.1 & 18.8 \\
14 & 11.7 & 25.6 & 23.8 & 22.7 & 20.8 & 16.8 \\
15 & 20.1 & 21.6 & 112.4 & 16.0 & 16.7 & 20.6 \\
16 & & & & & & 60.7 \\
17 & & & & & 14.5 \\
$a$ & Overlapped by solvent reagents. & & &
\end{tabular}


aliphatic ones at $\delta_{\mathrm{C}} 36.8$ and 56.0; an olefinic one at $\delta_{\mathrm{C}} 128.1$ ), five quaternary carbons (three olefinic ones at $\delta_{\mathrm{C}} 135.7,153.8$, and 141.2; an oxygenated aliphatic one at $\delta_{\mathrm{C}} 86.0$; an $\alpha, \beta$ unsaturated keto carbonyl group at $\left.\delta_{\mathrm{C}} 194.6\right)$. The ${ }^{1} \mathrm{H}-{ }^{1} \mathrm{H}$ COSY correlations (Fig. 2) between $\mathrm{H}-5$ and $\mathrm{H}-4 / \mathrm{H}-6, \mathrm{H}-4$ and $\mathrm{H}-3 / \mathrm{H}-5$ / Me-15, and $\mathrm{H}-2$ and $\mathrm{H}-3$ allowed the formation of $\mathrm{C} 2-\mathrm{C} 3-$ C4(C15)-C5-C6 moiety. A rather weak correlation was displayed between $\mathrm{H}-9$ and Me-14 in the ${ }^{1} \mathrm{H}-{ }^{1} \mathrm{H}$ COSY spectrum, and a rather small coupling constant $\left({ }^{4} J_{9,14}=1.2 \mathrm{~Hz}\right)$ was also observed in ${ }^{1} \mathrm{H}$ NMR, indicating $\mathrm{H}-9$ and Me-14 are in an allylic system. In addition, the observed HMBC correlation from Me14 to $\mathrm{C}-10 / \mathrm{C}-9$ suggested the aforementioned allylic system is C14-C10-C9. Furthermore, the HMBC correlations (Fig. 2) from $\mathrm{H}-14$ to C-1, H-3 to C-1, H-4 to C-1, H-5 to C-7, Me-12/Me-13 to C$11 / \mathrm{C}-7$, and $\mathrm{H}-6$ to $\mathrm{C}-8$ indicated $\mathrm{C}-1$ is linked with C-10, C-2 is attached to $\mathrm{C}-1, \mathrm{C}-5$ is attached to $\mathrm{C}-1, \mathrm{C}-7$ is attached to $\mathrm{C}-6$, Me-12/Me-13 are linked with C-11, and C-8 is linked with C-8. The above data determined the planar structure of $\mathbf{4}$, which is a guaiane-type sesquiterpene. The NOESY spectrum of 4 displayed correlations (Fig. 2) between $\mathrm{H}-6 \mathrm{a}\left(\delta_{\mathrm{H}} 2.62\right)$ and $\mathrm{H}-5 / \mathrm{Me}-$ $15 / \mathrm{Me}-12, \mathrm{H}-3 \mathrm{~b}\left(\delta_{\mathrm{H}} 1.25\right)$ and $\mathrm{H}-4 / \mathrm{H}-2 \mathrm{a}\left(\delta_{\mathrm{H}} 1.99\right)$, and $\mathrm{H}-2 \mathrm{~b}\left(\delta_{\mathrm{H}}\right.$ 1.92) and $1-\mathrm{OH}$, which suggest $\mathrm{H}-5, \mathrm{Me}-15$, and $1-\mathrm{OH}$ are all on the same side of the cyclic system and are specified as $\alpha$ oriented. The absolute configuration of 4 was elucidated by the quantum chemistry calculations on ECD spectra. Firstly, the ECD calculations were conducted using TDDFT method at the $\omega b 97 x d / d e f 2 t z v p$ level in methanol. The overall calculated ECD spectrum of each configuration was then generated according to the Boltzmann weighting of the conformers with Boltzmannpopulation of over $1 \%$. The tendency of the experimental ECD spectrum of 4 was similar to that of the calculated $(1 S, 4 R, 5 S)-4$ (Fig. 3), confirming the absolute configuration of 4 to be $1 S, 4 R, 5 S$.

Calamusin $\mathrm{P}$ (5) was assigned the molecular formula $\mathrm{C}_{15} \mathrm{H}_{24} \mathrm{O}_{2}$ on the basis of HRESIMS $\left(\mathrm{m} / \mathrm{z} 237.1849[\mathrm{M}+\mathrm{H}]^{+}\right)$and NMR spectra. ${ }^{1} \mathrm{H}$ NMR spectrum (Table 2) displayed proton signals corresponding to two secondary methyl groups $\left[\delta_{\mathrm{H}} 0.88\right.$ (d, $J=6.6 \mathrm{~Hz})$, Me-12; 0.89 (d, $J=5.4 \mathrm{~Hz}$ ), Me-13], two tertiary methyl groups $\left[\delta_{\mathrm{H}} 0.90(\mathrm{~s}), \mathrm{Me}-14 ; 1.99(\mathrm{~m}), \mathrm{Me}-15\right] .{ }^{13} \mathrm{C} \mathrm{NMR}$ (Table 3) and DEPT 135/90 spectra showed 15 carbon signals corresponding to four methyl groups, four methylenes, three methines, and four quaternary carbons (an oxygenated aliphatic one at $\delta_{\mathrm{C}} 74.1$; two olefinic ones at $\delta_{\mathrm{C}} 154.8$ and 138.1; an $\alpha, \beta$ unsaturated keto carbonyl group at 203.5). The ${ }^{1} \mathrm{H}-{ }^{1} \mathrm{H}$ COSY spectrum showed correlations (Fig. 2) corresponding to C1-C2-
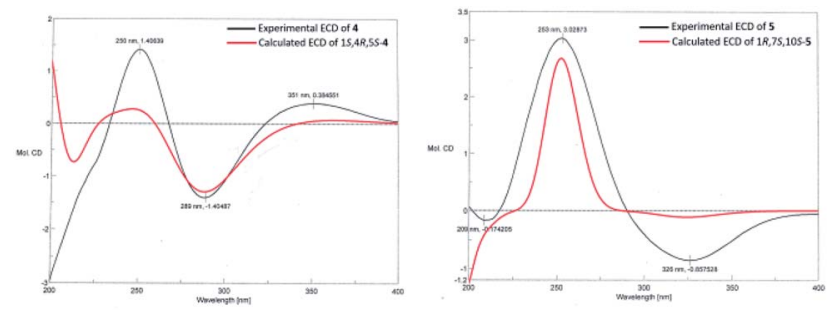

Fig. 3 Calculated and experimental ECD spectra of compounds 4 and 5 .
$\mathrm{C} 3$ and $\mathrm{C} 9-\mathrm{C} 8-\mathrm{C} 7-\mathrm{C} 11(\mathrm{C} 12)-\mathrm{C} 13$ moieties. In the HMBC spectrum, correlations (Fig. 2) from H-11 to C-6, H-7 to C-5, Me-15 to C-3/C-4/C-5, H-2 to C-5, and Me-14 to C-1/C-10/C-9 suggested C-6 is linked with C-7, C-5 is linked with C-6, C-4 is attached to C-3 and C-15, C-5 is linked with C-1, and C-10 is linked with Me-14/ C-1/C-9, indicating it possesses a carbon skeleton of guaianetype sesquiterpene. In the NOESY spectrum of 5 , cross signals (Fig. 2) of $\mathrm{H}-11$ with $\mathrm{H}-8 \mathrm{a}\left(\delta_{\mathrm{H}} 1.82\right)$ and $\mathrm{H}-8 \mathrm{~b}\left(\delta_{\mathrm{H}} 1.17\right)$ with Me14 indicated the isopropyl group at position 7, 10-OH, and $\mathrm{H}-8 \mathrm{a}$ are located on the same side (specified to be $\beta$-oriented) of the ring system, and $\mathrm{H}-8 \mathrm{~b}$ and $\mathrm{Me}-14$ ( $\alpha$-oriented) are on the other side of the ring system. Additionally, the NOESY correlation between $\mathrm{H}-1$ and $\mathrm{H}-7$ indicated $\mathrm{H}-1$ is $\alpha$-oriented. The absolute configuration of $\mathbf{5}$ was determined with the same method as compound 4 . The tendency of the experimental ECD spectrum of 5 was similar to that of the calculated $(1 R, 7 S, 10 S)-5$ (Fig. 3), confirming the absolute configuration of 5 to be $1 R, 7 S, 10 S$.

Calamusin Q (6) was deduced to have the molecular formula $\mathrm{C}_{17} \mathrm{H}_{26} \mathrm{O}_{5}$ by combined analysis of HRESIMS $(\mathrm{m} / \mathrm{z} 311.1859[\mathrm{M}+$ $\mathrm{H}]^{+}$) and NMR spectra. The IR spectrum showed the absorptive bands corresponding to hydroxyl $\left(3439 \mathrm{~cm}^{-1}\right)$ and carbonyl $\left(1724 \mathrm{~cm}^{-1}\right.$ ) groups. ${ }^{1} \mathrm{H}$ NMR spectrum (Table 2$)$ showed proton signals corresponding to an ethoxyl group $\left[\delta_{\mathrm{H}} 4.12(\mathrm{q}, J=7.2\right.$ $\mathrm{Hz}$ ), H-16; 1.22 (t, $J=7.2 \mathrm{~Hz}$ ), Me-17], one secondary methyl group $\left[\delta_{\mathrm{H}} 0.96(\mathrm{~d}, J=7.2 \mathrm{~Hz}), \mathrm{Me}-10\right]$, and three tertiary methyl groups $\left[\delta_{\mathrm{H}} 1.56(\mathrm{~s}), \mathrm{Me}-13 ; 1.57\right.$ (s), Me-14; 1.27 (s), Me-15]. A resonance corresponding to an oxygen-bearing methine was also observed $\left[\delta_{\mathrm{H}} 4.14(\mathrm{~m}), \mathrm{H}-3\right]$ in ${ }^{1} \mathrm{H}$ NMR spectrum. In addition, it showed resonance signals assignable to several aliphatic methylenes and methines between $\delta_{\mathrm{H}} 2.05$ and 3.00. ${ }^{13} \mathrm{C}$ NMR (Table 3) and DEPT-135/90 spectra showed 17 carbon signals corresponding to five methyl groups, four methylenes (an oxygenated one at $\delta_{\mathrm{C}} 60.7$ ), two methines (an oxygenated one at $\delta_{\mathrm{C}} 81.1$ ), and six quaternary carbons (a ketone carbonyl group at $\delta_{\mathrm{C}} 207.7$; an ester carbonyl group at $\delta_{\mathrm{C}} 173.1$; a double band at $\delta_{\mathrm{C}}$ 151.1 and 101.5; an oxygenated one at $\left.\delta_{\mathrm{C}} 74.7\right)$. Additionally, the olefinic carbon C-11 must be linked with an oxygen atom according to its chemical shift $\left(\delta_{\mathrm{c}-11} 151.1\right)$. The cross signals observed in ${ }^{1} \mathrm{H}-{ }^{1} \mathrm{H}$ COSY spectrum indicated the presence of structural units of $\mathrm{C} 16-\mathrm{C} 17, \mathrm{C} 8-\mathrm{C} 7-\mathrm{C} 10$, and $\mathrm{C} 2-\mathrm{C} 3$. The HMBC spectrum displayed cross peaks of Me-13 and C-14/12/ $11, \mathrm{H}-16$ and $\mathrm{C}-9, \mathrm{H}-8$ and $\mathrm{C}-1, \mathrm{H}-7$ and $\mathrm{C}-2 / 6, \mathrm{Me}-15$ and $\mathrm{C}-3 /$ $4 / 5,-\mathrm{OH}$ and $\mathrm{C}-4, \mathrm{H}-6$ and $\mathrm{C}-4 / \mathrm{C}-5$, and $\mathrm{H}-6$ and $\mathrm{C}-11$ indicating Me-13/Me-14 is attached to $\mathrm{C}-12$, the ethoxyl group is linked with C-9, C-1 is linked with C-7/C-2/C-6, C-4 is linked with $\mathrm{C}-3 / 5 / 15$, the hydroxyl group is linked with $\mathrm{C}-4, \mathrm{C}-5$ is linked with $\mathrm{C}-6$, and $\mathrm{C}-11$ is attached to $\mathrm{C}-1$. Furthermore, the HMBC correlation from $\mathrm{H}-3$ to C-11 and the chemical shifts of C-3 $\left(\delta_{\mathrm{C}}\right.$ 81.1) and $\mathrm{C}-11\left(\delta_{\mathrm{C}} 151.1\right)$ indicated that an oxygen bridge connected $\mathrm{C}-3$ and $\mathrm{C}-11$.

The NOESY correlation between the protons of Me-13 and Me-15 suggested Me-15 and the oxygen bridge are on the same side of the cyclohexanone unit, then the hydroxyl group and C-7 are on the other side. A positive Cotton effect occurred at $302 \mathrm{~nm}(\Delta \varepsilon+0.65)$ in $\mathrm{CD}$ spectrum indicated the absolute configurations of the chiral centers at the cyclohexanone unit 
are $1 S, 3 R, 4 S$, according to the $\mathrm{n} \rightarrow \pi^{*}$ transition of saturated cyclopentanone. ${ }^{31}$

According to the empirical isoprene rule, compound 6 can't be considered as a sesquiterpene. However, as our conjecture, the biogenic precursors of $\mathbf{6}$ is a previously reported acorane type sesquiterpenoid, calamusin $\mathrm{D}^{16}$ in which a series of oxidation, dehydration, oxidative cleavage, and ethylation reactions occurred to yield compound 6 (Fig. 4). As this conjecture, the absolute configuration of C-7 in compound 6 should be $S$, the same as C-4 in compound calamusin D. This was supported by NMR chemical shifts calculations of both the possible isomers $6 \mathbf{a}(1 S, 3 R, 4 S, 7 S)$ and $\mathbf{6 b}(1 S, 3 R, 4 S, 7 R)$ using the GIAO method at the mPW1PW91/6-311G(d,p) level in acetone. The calculated ${ }^{1} \mathrm{H}$ and ${ }^{13} \mathrm{C}$ NMR chemical shifts of the two possible isomers were compared with the experimental values of 6 by utilizing DP4+ probability analysis, which showed that $\mathbf{6 a}$ was predicted to be correct with probabilities of $100 \%$ for the ${ }^{1} \mathrm{H}$ NMR data, $93.4 \%$ for the ${ }^{13} \mathrm{C}$ NMR data, and $100 \%$ for their combination. The absolute configuration of 6 was thus proposed to be $1 S, 3 R, 4 S, 7 S$.

The known compounds were identified by comparison of their spectroscopic data with reported data. They were hedytriol $(7),{ }^{34},(-)-1 \beta, 4 \beta, 7 \alpha$-trihydroxyeudesmane $(8),{ }^{35}$ oplodiol $(9),{ }^{36} 6$ eudesmene- $1 \beta, 4 \beta$-diol $\quad(\mathbf{1 0}),{ }^{37} \quad 4 \beta, 5 \alpha, 10 \beta$-trihydroxycadinan (11) ${ }^{38}$ tatarinowin A (12), ${ }^{25}$ bullatantriol (13), ${ }^{39}$ homalomenol A $(\mathbf{1 4}),{ }^{40} 4^{\prime}$-dihydrophaseic acid (15), ${ }^{41}$ blumenol C $(\mathbf{1 6}),{ }^{42},(6 R, 9 S)$ 9-hydroxy-4-megastigmen-3-one (17), ${ }^{42}, \quad(+)$-dehydrovomifoliol (18), ${ }^{43}$ 1,10-seco-4 $\xi$-hydroxy-muurol-5-ene-1,10-diketone (19), ${ }^{44}$ and 2-hydroxyacorenone (20). ${ }^{45}$

Compounds 1-6 were evaluated for their neuroprotective effect on PC12 cells induced by serum withdrawal, rotenone, and OGD (Oxygen and Glucose Deprivation) in vitro with MTT method. As shown in Table 4, compounds 1 and 6 increased the cell survival rate of the OGD-treated group moderately, while compounds $\mathbf{3}$ and $\mathbf{5}$ decreased the cell survival rate of the serum withdrawal-treated PC12 cells moderately, and none of the compounds showed activity in the rotenone-treated models at $10 \mu \mathrm{M}$. Few investigations have been taken previously about neuroprotective activity and the corresponding mechanisms of
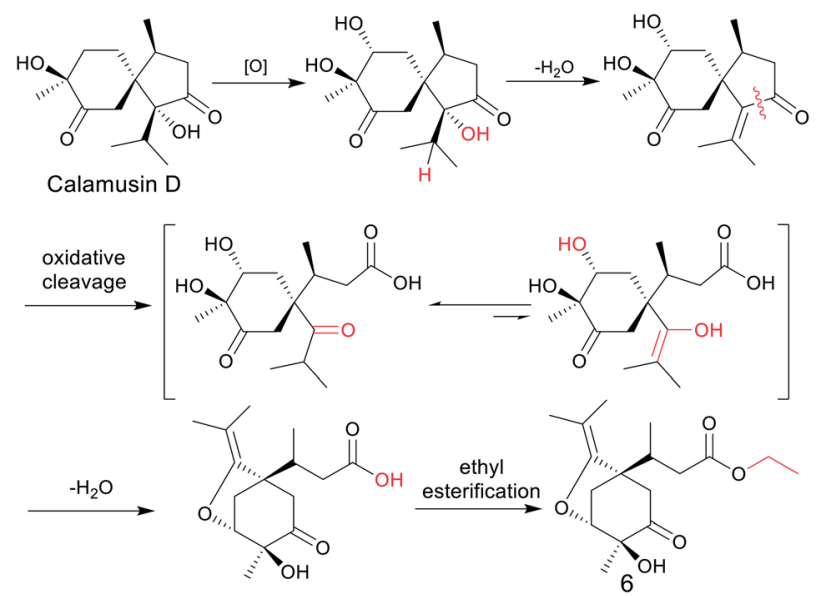

Fig. 4 Plausible biosynthetic pathway of compound 6 .
Table 4 Effects of compounds 1-6 to serum deprivation-, rotenone-, and OGD-induced injuries of PC12 cells in vitro (means $\pm \mathrm{SD}, n=3)^{a}$

\begin{tabular}{lccc}
\hline Compounds & Serum withdrawal & Rotenone & OGD \\
\hline Control & $100.0 \pm 7.2$ & $100.0 \pm 5.9$ & $100.0 \pm 6.2$ \\
Model & $51.0 \pm 5.6^{\# \# \#}$ & $71.0 \pm 6.1^{\text {\#\#\# }}$ & $58.2 \pm 7.7^{\text {\#\# }}$ \\
$\mathbf{1}$ & $47.2 \pm 4.5$ & $71.3 \pm 4.6$ & $74.3 \pm 8.2^{* *}$ \\
$\mathbf{2}$ & $46.1 \pm 4.1$ & $73.7 \pm 6.1$ & $60.2 \pm 8.5$ \\
$\mathbf{3}$ & $41.6 \pm 5.8^{* *}$ & $68.2 \pm 4.8$ & $63.3 \pm 9.0$ \\
$\mathbf{4}$ & $47.7 \pm 3.7$ & $69.9 \pm 5.2$ & $63.4 \pm 8.6$ \\
$\mathbf{5}$ & $43.2 \pm 5.6^{* *}$ & $68.6 \pm 4.7$ & $60.7 \pm 8.4$ \\
$\mathbf{6}$ & $46.5 \pm 6.7$ & $72.4 \pm 6.8$ & $68.9 \pm 7.6^{*}$
\end{tabular}

${ }^{a \#} p<0.01$ vs. control; ${ }^{*} p<0.05,{ }^{* *} p<0.01$ vs. model.

sesquiterpenes from A. calamus. However, a study by Li et al. ${ }^{19}$ indicated the sesquiterpenes, calamusin D (with a same carbon skeleton of compound 1) and acoric acid (with a same carbon skeleton of compound 6), showed significant cell proliferation activity on the human neuroblastoma cell line SK-N-BE (2), suggesting the both possessed neuroprotective activity. Therefore, more sesquiterpenes of diverse types, such as acorane- and 1,2-secoacorane-types, should be evaluated for their neuroprotective activity, and what's more, the action mechanisms and structure-activity relationships should be investigated in the future to discover the drug leads to treat neurodegenerative diseases.

\section{Experimental}

\section{General experimental procedures}

Optical rotations were measured with a JASCO P-2000 polarimeter. UV spectra were recorded on a JASCO V-650 spectrophotometer. IR spectra were recorded on a Nicolet 5700 spectrometer using FT-IR microscope transmission method. NMR spectra were recorded with Varian INOVA-600 and Bruker AV-600 spectrometers. HRESIMS were obtained on an Agilent 1100 series LC/MSD ion trap mass spectrometer. CD spectra were recorded on a JASCO J-815 spectropolarimeter. Analyticl HPLC was carried out on an Agilent 1200 INFINITY system with an Agilent ZORBAX SB-C18 column ( $5 \mu \mathrm{m}, 4.6 \times 150 \mathrm{~mm})$. Semipreparative HPLC was carried out on a Shimadzu LC-6AD pump with a Shimadzu SPD-M20A detector, an Agilent ZORBAX SBC18 column $(9.4 \times 250 \mathrm{~mm}, 5 \mu \mathrm{m})$, and an YMC-PACK SIL-06 column $(20 \mathrm{~mm} \times 250 \mathrm{~mm}, 5 \mu \mathrm{m})$. Colum chromatography was performed on silica gel (200-300 mesh, Qingdao Marine Chemical Factory, China), Sephadex LH-20 (GE) and ODS (50 $\mu \mathrm{m}, \mathrm{YMC}$, Japan), respectively. TLC was carried out with GF254 plates (Qingdao Marine Chemical Factory, China).

\section{Plant material}

The rhizomes of $A$. calamus were purchased from a Chinese herb store in Anguo county, Hebei Province, China, and authenticated by Professor Lin Ma, Institute of Materia Medica, Chinese Academy of Medical Sciences and Peking Union Medical College. A voucher specimen (no. ID-S-2281) has been deposited at the Herbarium of the Institute of Material Medica, 
Chinese Academy of Medical Sciences and Peking Union Medical College, China.

\section{Extraction and isolation}

Dried rhizomes of A. calamus (19.8 kg) were smashed and extracted with $95 \%$ ethanol $(3 \times 2 \mathrm{~h})$. The concentrated extract $(3.1 \mathrm{~kg})$ was suspended in water $(3 \mathrm{~L})$ and partitioned with petroleum ether, ethyl acetate and $n$-butanol $(3 \mathrm{~L} \times 3)$, successively. The EtOAc portion (310 g) was subjected to silica gel column $(10.5 \times 100 \mathrm{~cm})$ eluted with $\mathrm{CH}_{2} \mathrm{Cl}_{2} / \mathrm{MeOH}(40: 1$, $20: 1,15: 1,10: 1,8: 1,6: 1,5: 1,3: 1,1: 1,0: 1 ; \mathrm{v} / \mathrm{v})$ to give ten fractions (F1-F10). F6 (21 g) was chromatographed with silica gel $(200-300$ mesh, $10 \times 60 \mathrm{~cm})$ eluting with a gradient of $\mathrm{CH}_{2} \mathrm{Cl}_{2}: \mathrm{MeOH}(10: 1,7: 1,5: 1,3: 1,0: 1)$ to give five fractions, named F6a-F6e. F6a (2.3 g) was chromatographed on a reversed phase $\mathrm{C}_{18}$ silica gel column $(4.5 \times 42 \mathrm{~cm})$ with a gradient $\mathrm{MeOH}-\mathrm{H}_{2} \mathrm{O}(30: 70,50: 50,70: 30,100: 0)$ to give six fractions, named F6a1-F6a6. F6a2 was purified by normalphase silica gel semi-preparative HPLC (87\% $n$-hexane/2propanol, $4 \mathrm{~mL} \mathrm{~min}^{-1}$ ) to yield $1\left(5.5 \mathrm{mg}, t_{R}=50.5 \mathrm{~min}\right)$. F6a3 was purified by $\mathrm{C}_{18}$ ODS semi-preparative HPLC $(25 \%$ $\left.\mathrm{MeCN} / \mathrm{H}_{2} \mathrm{O}, 2.5 \mathrm{~mL} \mathrm{~min}^{-1}\right)$ to yield $2\left(12.4 \mathrm{mg}, t_{R}=45.6 \mathrm{~min}\right)$ and 3 (5.5 $\left.\mathrm{mg}, t_{R}=39.2 \mathrm{~min}\right)$. F6a5 was purified by $\mathrm{C}_{18}$ ODS semi-preparative HPLC $\left(37.5 \% \mathrm{MeCN} / \mathrm{H}_{2} \mathrm{O}, 2.5 \mathrm{~mL} \mathrm{~min}^{-1}\right)$ to yield $12\left(2 \mathrm{mg}, t_{R}=42.4 \mathrm{~min}\right), 4\left(5.8 \mathrm{mg}, t_{R}=44.1 \mathrm{~min}\right), 20$ $\left(21.5 \mathrm{mg}, t_{R}=49.2 \mathrm{~min}\right)$, and $6\left(8.2 \mathrm{mg}, t_{R}=59.1 \mathrm{~min}\right)$. F6a6 was purified by $\mathrm{C}_{18}$ ODS semi-preparative HPLC $(54 \%$ $\left.\mathrm{MeCN}: \operatorname{MeOH}(1: 1) / \mathrm{H}_{2} \mathrm{O}, 2.5 \mathrm{~mL} \mathrm{~min}^{-1}\right)$ to yield compound 5 (4.7 $\left.\mathrm{mg}, t_{R}=28.5 \mathrm{~min}\right)$. F6b (5.7 g) was chromatographed on a reversed phase $\mathrm{C}_{18}$ silica gel column $(4.5 \times 42 \mathrm{~cm})$ with a gradient $\mathrm{MeOH}-\mathrm{H}_{2} \mathrm{O}(30: 70,50: 50,70: 30,100: 0)$ to give eight fractions, named F6b1-F6b8. F6b2 was chromatographed on Sephadex LH-20 column (MeOH) to give $7(20.8 \mathrm{mg})$ and 8 (5.5 mg). F6b3 was purified by $\mathrm{C}_{18}$ ODS preparative HPLC $(35 \%$ $\mathrm{MeCN}: \mathrm{MeOH} / \mathrm{H}_{2} \mathrm{O}, 5 \mathrm{~mL} \mathrm{~min}^{-1}$ ) to yield compound 9 (60.2 $\mathrm{mg}, t_{R}=112 \mathrm{~min}$ ). F6b5 was purified by $\mathrm{C}_{18}$ ODS semipreparative HPLC (26\% $\left.\mathrm{MeCN}: \mathrm{MeOH} / \mathrm{H}_{2} \mathrm{O}, 2.5 \mathrm{~mL} \mathrm{~min}^{-1}\right)$ to yield compound $10\left(16.8 \mathrm{mg}, t_{R}=118 \mathrm{~min}\right)$ and $14\left(5.1 \mathrm{mg}, t_{R}=\right.$ $125 \mathrm{~min})$. F6b4 was chromatographed over silica gel (PE : acetone, $3: 1)$ to give $11(10.3 \mathrm{mg})$. F6c was chromatographed on a reversed phase $\mathrm{C}_{18}$ silica gel column $(4.5 \times 42 \mathrm{~cm})$ with a gradient $\mathrm{MeOH}-\mathrm{H}_{2} \mathrm{O}(30: 70,50: 50,70: 30,100: 0)$ to give 7 fractions, named F6c1-F6c7. F6c1 was chromatographed over Sephadex LH-20 (MeOH), followed by recrystallization in acetone, to give $13(15.2 \mathrm{mg})$. F6c2 was purified by $\mathrm{C}_{18}$ ODS semi-preparative HPLC ( $\left.8 \% \mathrm{MeCN}: \mathrm{MeOH} / \mathrm{H}_{2} \mathrm{O}, 2.5 \mathrm{~mL} \mathrm{~min}^{-1}\right)$ to yield compound 15 (6.0 mg, $\left.t_{R}=59.6 \mathrm{~min}\right)$. F6c 3 was purified by $\mathrm{C}_{18}$ ODS semi-preparative HPLC $\left(35 \% \mathrm{MeOH} / \mathrm{H}_{2} \mathrm{O}, 2.5\right.$ $\left.\mathrm{mL} \mathrm{min}^{-1}\right)$ to yield compound 16 (3.6 mg, $\left.t_{R}=110 \mathrm{~min}\right)$ and 17 (4.6 mg, $t_{R}=115 \mathrm{~min}$ ). F6c4 was purified by $\mathrm{C}_{18}$ ODS semipreparative HPLC $\left(12 \% \mathrm{MeCN} / \mathrm{H}_{2} \mathrm{O}, 2.5 \mathrm{~mL} \mathrm{~min}^{-1}\right)$ to yield compound 18 (2.5 mg, $\left.t_{R}=61.7 \mathrm{~min}\right)$. $\mathrm{F} 6 \mathrm{c} 6$ was purified by $\mathrm{C}_{18}$ ODS semi-preparative $\mathrm{HPLC}\left(41 \% \mathrm{MeCN} / \mathrm{H}_{2} \mathrm{O}, 2.5 \mathrm{~mL} \mathrm{~min}{ }^{-1}\right)$ to yield compound 19 ( $\left.4.3 \mathrm{mg}, t_{R}=10.0 \mathrm{~min}\right)$.

Calamusin L (1). Colorless oil (MeOH); $[\alpha]_{\mathrm{D}}^{20}-50.4$ (c 0.11); $\mathrm{UV}(\mathrm{MeOH}) \lambda_{\max }(\log \varepsilon) 269 \mathrm{~nm}$ (4.69); CD (MeOH) $\lambda_{\max }(\Delta \varepsilon)$ :
$315 \mathrm{~nm}$ (-1.29), $273 \mathrm{~nm}(-1.29), 224 \mathrm{~nm}(+0.78)$; IR $\nu_{\max } 3390$, $1708,1411,1372,1077 \mathrm{~cm}^{-1}$; for ${ }^{1} \mathrm{H}\left(600 \mathrm{MHz}\right.$, acetone- $\left.d_{6}\right)$ and ${ }^{13} \mathrm{C}$ NMR (150 MHz, acetone- $d_{6}$ ) data, see Tables 1 and 3; HRESIMS $m / z: 299.1490[\mathrm{M}+\mathrm{H}]^{+}$(calcd for $\mathrm{C}_{15} \mathrm{H}_{23} \mathrm{O}_{6}, 299.1495$ ), $321.1313[\mathrm{M}+\mathrm{Na}]^{+}$(calcd for $\mathrm{C}_{15} \mathrm{H}_{22} \mathrm{O}_{6} \mathrm{Na}, 321.1314$ ).

Calamusin $\mathbf{M}$ (2). White amorphous powder $(\mathrm{MeOH})$; $[\alpha]_{\mathrm{D}}^{20}+65.9(c \quad 0.53, \mathrm{MeOH}) ; \mathrm{UV}(\mathrm{MeOH}) \lambda_{\max }(\log \varepsilon) 226 \mathrm{~nm}$ (3.94); CD (MeOH) $\lambda_{\max }(\Delta \varepsilon) 343 \mathrm{~nm}$ (1.03), $242 \mathrm{~nm}(-5.11)$, $219 \mathrm{~nm}(-0.31)$; IR $\nu_{\max } 3384,2957,1670,1437,1375,1259$, $1041 \mathrm{~cm}^{-1}$; For ${ }^{1} \mathrm{H}\left(600 \mathrm{MHz}\right.$, acetone- $\left.d_{6}\right)$ and ${ }^{13} \mathrm{C}$ NMR (150 MHz, acetone- $\left.d_{6}\right)$ data, see Tables 1 and 3; HRESIMS: $\mathrm{m} / \mathrm{z}$ 291.1575 $[\mathrm{M}+\mathrm{Na}]^{+}$(calcd for $\mathrm{C}_{15} \mathrm{H}_{24} \mathrm{O}_{4} \mathrm{Na}, 291.1572$ ).

Calamusin N (3). Colorless oil $(\mathrm{MeOH}) ;[\alpha]_{\mathrm{D}}^{20}+23.4(c$ 0.553, $\mathrm{MeOH})$; IR $\nu_{\max } 3372,3288,2956,1464,1439,1140,1047$, $905 \mathrm{~cm}^{-1}$; for ${ }^{1} \mathrm{H}\left(600 \mathrm{MHz}\right.$, acetone- $\left.d_{6}\right)$ and ${ }^{13} \mathrm{C} \mathrm{NMR}(150 \mathrm{MHz}$, acetone- $d_{6}$ ) data, see Tables 1 and 3; HRESIMS $m / z: 277.1777$ [M $+\mathrm{Na}]^{+}$(calcd for $\mathrm{C}_{15} \mathrm{H}_{26} \mathrm{O}_{3} \mathrm{Na}, 277.1780$ ).

Calamusin O (4). Colorless oil $(\mathrm{MeOH}) ;[\alpha]_{\mathrm{D}}^{20}+5.8(c$ 0.125, $\mathrm{MeOH}) ; \mathrm{UV}(\mathrm{MeOH}) \lambda_{\max }(\log \varepsilon) 251 \mathrm{~nm}$ (3.72), $202 \mathrm{~nm}$ (3.81); $\mathrm{CD}(\mathrm{MeOH}) \lambda_{\max }(\Delta \varepsilon): 351 \mathrm{~nm}(0.38), 289 \mathrm{~nm}(-1.40), 250 \mathrm{~nm}$ (+1.41); IR $\nu_{\max } 3413,2957,1710,1642,1449,1375,1299 \mathrm{~cm}^{-1}$; for ${ }^{1} \mathrm{H}\left(600 \mathrm{MHz}\right.$, acetone- $\left.d_{6}\right)$ and ${ }^{13} \mathrm{C}$ NMR (150 MHz, acetone$d_{6}$ ) data, see Tables 2 and 3; HRESIMS: $m / z$ 235.1688 $[\mathrm{M}+\mathrm{H}]^{+}$ (calcd 235.1698).

Calamusin P (5). Colorless oil (MeOH); $[\alpha]_{\mathrm{D}}^{20}+20.0(c 0.463$, $\mathrm{MeOH})$; UV (MeOH) $\lambda_{\max }(\log \varepsilon) 253 \mathrm{~nm}(3.80) ; \mathrm{CD}(\mathrm{MeOH}) \lambda_{\max }$ $(\Delta \varepsilon)$ : $326 \mathrm{~nm}(-0.86), 253 \mathrm{~nm}(+3.03)$; IR $\nu_{\max } 3422,2958,1670$, $1609,1462,1374,1194,1112 \mathrm{~cm}^{-1}$; for ${ }^{1} \mathrm{H}$ (600 MHz, acetone- $\left.d_{6}\right)$ and ${ }^{13} \mathrm{C}$ NMR (150 MHz, acetone- $d_{6}$ ) data, see Tables 2 and 3; HRESIMS: $m / z$ 237.1849 $[\mathrm{M}+\mathrm{H}]^{+}$(calcd for $\mathrm{C}_{15} \mathrm{H}_{25} \mathrm{O}_{2}, 237.1855$ ).

Calamusin Q (6). Colorless oil $(\mathrm{MeOH}) ;[\alpha]_{\mathrm{D}}^{20}+3.1$ (c 0.169, $\mathrm{MeOH}) ; \mathrm{UV}(\mathrm{MeOH}) \lambda_{\max }(\log \varepsilon) 202 \mathrm{~nm}$ (4.01); CD (MeOH) $\lambda_{\max }$ $(\Delta \varepsilon): 348 \mathrm{~nm}(-0.04), 302 \mathrm{~nm}(+0.65), 249 \mathrm{~nm}(-0.18), 222 \mathrm{~nm}$ $(+0.74)$; IR $\nu_{\max } 3439,2980,1724,1457,1374,1303,1177$, $1100 \mathrm{~cm}^{-1}$; for ${ }^{1} \mathrm{H}\left(600 \mathrm{MHz}\right.$, acetone- $\left.d_{6}\right)$ and ${ }^{13} \mathrm{C}$ NMR (150 MHz, acetone- $d_{6}$ ) data, see Tables 2 and 3; HRESIMS: $\mathrm{m} / \mathrm{z}$ $311.1859[\mathrm{M}+\mathrm{H}]^{+}$(calcd for $\mathrm{C}_{17} \mathrm{H}_{27} \mathrm{O}_{5}, 311.1858$ ), $333.1682[\mathrm{M}+$ $\mathrm{Na}]^{+}$(calcd for $\mathrm{C}_{17} \mathrm{H}_{26} \mathrm{O}_{5} \mathrm{Na}, 333.1678$ ).

\section{Specific optical rotation, ECD, and NMR calculations}

Conformational analyses were carried out via random searching in the GMMX software using the MMFF94 force field. Subsequently, the conformers were re-optimized using DFT at the B97D/TZVP or wb97xd/def2tzvp levels in MeOH by the GAUSSIAN 16 program. ${ }^{46}$ The SORs of conformers of 3 were calculate at the pbe1pbe/aug-ccpVTZ level. The ECD spectra of conformers of compounds 4 and 5 were calculated using the TDDFT methodology at the wb97xd/ def2tzvp level. The calculated SORs and ECD spectra of the conformers were averaged according to the Boltzmann distribution theory and their relative Gibbs free energy $(\Delta G)$.

Geometrically optimized conformers for the possible diastereomers of $\mathbf{6 a} / \mathbf{6} \mathbf{b}$ proceeded to GIAO magnetic shielding constants at the mPW1PW91/6-311G(d,p) level. The NMR chemical shifts of the isomers were obtained by Boltzmann averaging of the ${ }^{1} \mathrm{H}$ and ${ }^{13} \mathrm{C}$ NMR chemical shifts of the stable conformers. ${ }^{47}$ The calculated NMR properties of the optimized 
structures were averaged as described above, and DP4+ probability analysis was facilitated using an Excel sheet (DP4+) provided by Grimblat et al. ${ }^{48}$

\section{Neuroprotective assays}

The in vitro neuroprotective activity was tested by the method described previously. ${ }^{\mathbf{4 9 , 5 0}}$

\section{Conclusions}

Six new sesquiterpenes, named calamusins L-Q (1-6), were isolated from the rhizomes of $A$. calamus, together with fourteen known ones. The new compounds and their absolute configurations were determined based on extensive spectroscopic analyses and computational methods. It was hypothesized that compound 6 was a secosesquiterpene, which was formed from calamusin D during the biosynthesis after a series of oxidation, dehydration, oxidative cleavage, and ethylation reactions. Furthermore, compounds 1-6 were tested for their neuroprotective effects, and it was observed that compounds 1 and $\mathbf{6}$ increased the cell survival rate of the OGD-treated PC12 cells moderately, while compounds $\mathbf{3}$ and $\mathbf{5}$ decreased the cell survival rate of the serum withdrawal-treated PC12 cells moderately.

\section{Conflicts of interest}

There are no conflicts to declare.

\section{Acknowledgements}

The project was financially supported by Chinese Academy of Medical Sciences Initiative for Innovative Medicine [CAMS-12M1-010], the State Key Laboratory of Bioactive Substance and Function of Natural Medicines (GTZA201803), and the Drug Innovation Major Project (2018ZX09711001-008-009).

\section{Notes and references}

1 Chinese Material Medica Editorial Board of Chinese Material Medica, Chinese Material Medica, Shanghai Scientific \& Technical Publishers, Shanghai, 1999.

2 S. R. Haghighi, M. H. Asadi, H. Akrami and A. Baghizadeh, Avicenna J. Phytomed., 2017, 7, 145-156.

3 K. A. Lopatina, E. A. Safonova, K. V. Nevskaya, M. N. Stakheeva, A. M. Gur'ev, E. P. Zueva, T. G. Razina, E. N. Amosova, S. G. Krylov and M. V. Belousov, Bull. Exp. Biol. Med., 2017, 164, 102-105.

4 B. K. Das, A. H. M. V. Swamy, B. C. Koti and P. C. Gadad, Heliyon, 2019, 5, e01585.

5 S. Reddy, G. Rao, B. Shetty and G. Hn, Turk. Neurosurg., 2015, 25, 425-431.

6 X. Yao, Y. Ling, S. Guo, W. Wu, S. He, Q. Zhang, M. Zou, K. S. Nandakumar, X. Chen and S. Liu, Phytomedicine, 2018, 42, 258-267.

7 A. Sagar and S. Rana, J. Pure and Appl. Microbio., 2012, 6, 1455-1460.
8 R. K. Joshi, World J. Microbiol. Biotechnol., 2016, 32, 164.

9 V. Chinappan, M. A. Prabha and G. Sivakumar, Faseb J, 2011, 25, 677.12.

10 A. Muthuraman and N. Singh, J. Ethnopharmacol., 2012, 142, 723-731.

11 S. Subamalani, A. Sasikumar, S. Manikandan and C. Ramaswamy, Int. J. Pharm. Sci. Res., 2018, 9, 4832-4841.

12 Y. X. Liu, M. M. Si, W. Lu, L. X. Zhang, C. X. Zhou, S. L. Deng and H. S. Wu, J. Ethnopharmacol., 2015, 166, 168-175.

13 S. Ahmed, S. Gul, M. Zia-Ul-Haq and M. S. Stankovic, Bol. Latinoam. Caribe Plant. Med. Aromat., 2014, 13, 38-46.

14 V. Sharma, R. Sharma, D. S. Gautam, K. Kuca, E. Nepovimova and N. Martins, J. Clin. Med., 2020, 9, 1176.

15 R. Tundis, M. Bonesi, F. Menichini and M. R. Loizzo, MiniRev. Med. Chem., 2016, 16, 605-618.

16 Z.-Y. Hao, D. Liang, H. Luo, Y.-F. Liu, G. Ni, Q.-J. Zhang, L. Li, Y.-K. Si, H. Sun, R.-Y. Chen and D.-Q. Yu, J. Nat. Prod., 2012, 75, 1083-1089.

17 C. X. Zhou, D. Qiao, Y. Y. Yan, H. S. Wu, J. X. Mo and L. S. Gan, Chin. Chem. Lett., 2012, 23, 1165-1168.

18 J. Li, J. P. Zhao, S. X. Li, B. Li, Y. W. Ou and Q. R. Liu, Chem. Nat. Compd., 2015, 51, 1099-1102.

19 J. Li, J. Zhao, W. Wang, L. Li, L. Zhang, X. F. Zhao, Q. R. Liu, F. Liu, M. Yang, I. A. Khan and S. X. Li, Molecules, 2017, 22, 529.

20 J. Li, Z. X. Li, J. P. Zhao, W. Wang, X. F. Zhao, B. Xu, L. Li, L. Zhang, J. Ren, I. A. Khan and S. X. Li, Chem. Biodiversity, 2017, 14, e1700201.

21 R. Kumar, S. Sharma, S. Sharma and N. Kumar, J. Appl. Res. Med. Aroma., 2016, 3, 136-141.

22 R. Shukla, P. Singh, B. Prakash and N. K. Dubey, J. Essent. Oil Bear. Pl., 2016, 19, 542-552.

23 S. Suzgec-Selcuk, G. Ozek, A. H. Mericli, K. H. C. Baser, Y. Haliloglu and T. Ozek, J. Essent. Oil Bear. Pl., 2017, 20, 646-661.

24 X. He, Q. Cai, J. Li and W. Guo, Neurosci. Lett., 2018, 666, 7884.

25 X.-G. Tong, G.-S. Wu, C.-G. Huang, Q. Lu, Y.-H. Wang, C.-L. Long, H.-R. Luo, H.-J. Zhu and Y.-X. Cheng, J. Nat. Prod., 2010, 73, 1160-1163.

26 Y. Yang, L. Xuan, H. Chen, S. Dai, L. Ji, Y. Bao and C. Li, Evid. Based Complement. Alternat. Med., 2017, 2017, 8516518.

27 K. Y. C. Lam, P. Yao, H. Y. Wang, R. Duan, T. T. X. Dong and K. W. K. Tsim, Plos One, 2017, 12, e0179077.

28 R. W. Wiseman, E. C. Miller, J. A. Miller and A. Liem, Cancer Res., 1987, 47, 2275-2283.

29 T. Uebel, L. Hermes, S. Haupenthal, L. Muller and M. Esselen, J. Appl. Toxicol., 2020, 1-14.

30 G. Ni, G. R. Shi, D. Zhang, N. J. Fu, H. Z. Yang, X. G. Chen and D. Q. Yu, Planta Med., 2016, 82, 632-638.

$31 \mathrm{H}$. B. Kagan, Determination of Configurations by Dipole Moments, Determination of Configurations by Dipole Moments, CD or ORD, Thieme Publishers, Stuttgart, 1977.

32 X. L. Feng, Y. Yu, H. Gao, Z. Q. Mu, X. R. Cheng, W. X. Zhou and X. S. Yao, RSC Adv, 2014, 4, 42071-42077.

33 G. Snatzke, Tetrahedron, 1965, 21, 421-438. 
34 W. M. Zhu, Q. Zhao, S. L. Li and X. J. Hao, J. Asian Nat. Prod. Res., 2007, 9, 277-283.

35 J. E. de Menezes, F. E. Machado, T. L. Lemos, E. R. Silveira, R. Braz Filho and O. D. Pessoa, Z. Naturforsch., C: J. Biosci., 2004, 59, 19-22.

36 M. Ono, M. Yamashita, K. Mori, C. Masuoka, M. Eto, J. Kinjo, T. Ikeda, H. Yoshimitsu and T. Nohara, Food Sci. Tech. Res., 2008, 14, 499-508.

37 W. C. Su, J. M. Fang and Y. S. Cheng, Phytochemistry, 1995, 39, 603-607.

38 M. Andersson, O. Bergendorff, R. Shan, P. Zygmunt and O. Sterner, Planta Med., 1997, 63, 251-254.

39 T. V. Sung, B. Steffan, W. Steglich, G. Klebe and G. Adam, Phytochemistry, 1992, 31, 3515-3520.

40 K.-Y. Jung, D.-S. Kim, S.-R. Oh, I.-S. Lee, J.-J. Lee, H.-K. Lee, D.-H. Shin, E.-H. Kim and C.-J. Cheong, Arch. Pharm Res., 1997, 20, 363-367.

41 Z. Zhang, W. Zhang, Y. P. Ji, Y. Zhao, C. G. Wang and J. F. Hu, Phytochemistry, 2010, 71, 693-700.

42 B. D'Abrosca, M. DellaGreca, A. Fiorentino, P. Monaco, P. Oriano and F. Temussi, Phytochemistry, 2004, 65, 497-505.

43 H. Kai, M. Baba and T. Okuyama, Chem. Pharm. Bull., 2007, 55, 133-136.

44 K. S. Ngo, W. T. Wong and G. D. Brown, J. Nat. Prod., 1999, 62, 549-553.

45 K. Nawamaki and M. Kuroyanagi, Phytochemistry, 1996, 43, 1175-1182.

46 M. J. Frisch, G. W. Trucks, H. B. Schlegel, G. E. Scuseria, M. A. Robb, J. R. Cheeseman, G. Scalmani, V. Barone,
G. A. Petersson, H. Nakatsuji, X. Li, M. Caricato, A. V. Marenich, J. Bloino, B. G. Janesko, R. Gomperts, B. Mennucci, H. P. Hratchian, J. V. Ortiz, A. F. Izmaylov, J. L. Sonnenberg, Williams, F. Ding, F. Lipparini, F. Egidi, J. Goings, B. Peng, A. Petrone, T. Henderson, D. Ranasinghe, V. G. Zakrzewski, J. Gao, N. Rega, G. Zheng, W. Liang, M. Hada, M. Ehara, K. Toyota, R. Fukuda, J. Hasegawa, M. Ishida, T. Nakajima, Y. Honda, O. Kitao, H. Nakai, T. Vreven, K. Throssell, J. A. Montgomery Jr, J. E. Peralta, F. Ogliaro, M. J. Bearpark, J. J. Heyd, E. N. Brothers, K. N. Kudin, V. N. Staroverov, T. A. Keith, R. Kobayashi, J. Normand, K. Raghavachari, A. P. Rendell, J. C. Burant, S. S. Iyengar, J. Tomasi, M. Cossi, J. M. Millam, M. Klene, C. Adamo, R. Cammi, J. W. Ochterski, R. L. Martin, K. Morokuma, O. Farkas, J. B. Foresman and D. J. Fox, Gaussian 16, Revision A.03; Gaussian, Inc., Wallingford CT, 2016.

47 A. C. Carter, C. L. Petersen, K. L. Wendt, S. K. Helff, A. L. Risinger, S. L. Mooberry and R. H. Cichewicz, J. Nat. Prod., 2019, 82, 886-894.

48 N. Grimblat, M. M. Zanardi and A. M. Sarotti, J. Org. Chem., 2015, 80, 12526-12534.

49 H. J. Ji, D. M. Wang, J. F. Hu, M. N. Sun, G. Li, Z. P. Li, D. H. Wu, G. Liu and N. H. Chen, Eur. J. Pharmacol., 2014, 723, 259-266.

50 S. Y. Shao, Z. M. Feng, Y. N. Yang, J. S. Jiang and P. C. Zhang, Org. Biomol. Chem., 2017, 15, 7034-7039. 